\title{
RIDING DRESS HISTORY, WITH A TWIST: THE SIDE SADDLE HABIT AND THE HORSE DURING THE EARLY TWENTIETH CENTURY
}

\section{ALISON L GOODRUM}

\begin{abstract}
The discussion takes the form of an historical exegesis of the dress worn by female side saddle riders focusing on the early decades of the twentieth century and, geographically speaking, on the UK and the USA. The chapter unpacks the codes of dress and etiquette that governed the wearing of the side saddle 'habit'. It goes about this through two analytical routes that, together, combine artefacts (things) with textual sources (narratives). Firstly, the chapter traces back the heritage of today's female side saddlers through a consideration of 'evocative objects' such as antique saddles and the memories and historicised meanings bound up in them. Secondly, it draws on historical content presented in instructional manuals and printed advisories on correct riding 'turn out' from the years 1900 to 1939 . Much of the shape, form and styling of habit dress was led by practical concerns to do with safety, efficiency of performance and the facilitation of the partnership between horse and rider. Indeed, this latter point, one of the animal-human relationship, is especially significant to the framing of the chapter. For the broader intention is to open up an un(der)-explored trajectory for the historical study of the side saddle habit, which, to date, has focused more on (material) clothes and less on (corporeal) horse and/or rider. Remembering that the side saddle habit was worn in the pursuit of beastly activity on the back of a horse (and designed and styled accordingly), this chapter embarks on the task of writing the animal in to history and, in particular, of writing the horse in to riding dress history.
\end{abstract}


Our horse is a living being and, though in a sense we control his movements, yet the movements are his. Every horse gives us a different 'feel,' and it is this 'feel,' this movement, with which we want to be in harmony. Unless we are in harmony we do not get the true 'feel,' and it is only through close touch with our horse and a sense of balance, rhythm, and sympathy that this harmony can be attained.

(Doreen Archer Houblon, Side-Saddle, 1938, p. 7)

\section{INTRODUCTION}

This chapter offers context - the back story, if you will - to what we will see as an emerging, contemporary, cultural and sporting enthusiasm for side saddle riding. The discussion takes the form of an historical exegesis of the dress worn by female side saddle riders, focusing on the early decades of the twentieth century and, geographically speaking, on the UK and the USA. Foremost, the chapter is concerned with describing the codes of dress and etiquette that governed the wearing of the side saddle 'habit' (as it was, and is, termed), tracing back the heritage of today's female side saddlers to examine the historical provenance of their attire and appearance. At first glance, formal [note 1] female habit dress was deceptively simple, comprising an outfit of waistcoat, jacket and skirt (as well as accessories such as a top hat, stock tie, knee boots and close fitting breeches worn as under garments) that belied the richly nuanced, literal and metaphorical, layers of material and meaning beneath. The discussion here draws, in particular, on the advice presented in equestrian instruction manuals and printed advisories on the appearance and correct 'turn out' of female side saddle riders between the years 1900 and 1939. In presenting a dress history of the side saddle habit, the discussion highlights the origins and the evolution of this intriguing, esoteric, mode of dressing. It reveals how much of the shape, form and styling was led by practical concerns to 
do with safety, efficiency of performance and the facilitation of the partnership between horse and rider. Indeed, this latter point, one of the animal-human relationship, is especially significant to the framing of the chapter. For the broader intention here is to open up an un(der)-explored trajectory for the historical study of the side saddle habit, which, to date, has focused more on (material) clothes and less on (corporeal) horse and/or rider. This chapter attempts to reconcile the animal and the human with, and for, riding dress history, remembering that the side saddle habit was worn in the pursuit of beastly activity on the back of a horse, and was designed and styled accordingly. Simply put, and taking up Swart's (2007) challenge, the discussion embarks on locating 'the bloody horse' [note 2], and inserting it, in the academic fields of leisure, sport and dress history.

\section{ASIDE ON THE RISE: NOTES ON SIDE SADDLE RIDING TODAY}

Across its five centuries of practice, side saddle riding among women has witnessed peaks and troughs in popularity and prevalence, as well as in form and nature. It was not until the 1860s that the side saddle took on its current, modern, form (figure 1), comprising the familiar, two-pronged, 'pommel' and 'leaping head' arrangement (Druesdow, 1984; Grant, 1978; Peralta-Ramos, 2000). Side saddle riding enjoyed its heyday in a period spanning the Victorian 1880 s to the early 1930 s when upper-class women's participation in vigorous sporting pastimes such as foxhunting and cross country riding (much assisted by the leaping head innovation) gained social acceptability and popularity. Buxton $(1987$, p. 86) informs us that throughout the 1870s and 1880s the number of women in the hunting field increased considerably and cites Brooksby's [note 3] observation from 1877 'that there were tenfold as many as 12 years before: 30 in a field of 300.'

\footnotetext{
*Insert figure 1 about here*
} 
Figure 1: Side saddle and side saddle grip demonstrated by Alice Hayes, author of The Horsewoman (1903 [1893], p. 37). The side saddle comprises two leg struts: the 'leaping head' (downturned, right) and the 'fixed head' or 'upper pommel' (upturned, left). Note that Hayes uses a wooden trestle to simulate the horse, apparatus similar to that found in the equestrian tailor's fitting room.

More recently, during the second half of the twentieth century, side saddle riding for women fell out of favour and was regarded as a minority pursuit and an archaic, even oppressive, symbol of a bygone age. Side saddles, at this time, were broadly the reserve of pageants and historical re-enactments, and the preserve of female British Royals, including Queen Elizabeth II, on State Occasions. Writing in 1959, Lida Fleitmann Bloodgood (18941982), a celebrated exponent of the side saddle in the USA and Europe, lamented that riding aside had come to be 'as much an anachronism as the cabriolet, the crinoline, and the minuet' and pronounced that 'the saddle which carried us to victory in the show-ring and to glory in the hunting-field has had its day.'

Yet the perceived demise of the side saddle in the late 1950s was neither wholesale nor permanent. At the turn of the twenty-first century, and in current times in particular, side saddle riding is now witnessing yet another, positive, shift in its popularity and is undergoing something of a cult renaissance. As with any socio-cultural trend, the revival has been mobilised by a number of intersecting factors. For example, the side saddle seat is often favoured by therapeutic riding programmes. The arrangement of the legs, which are required to be wound around the two pommels of the saddle are considered to offer security and solidity of hold that is enabling to some with muscular impairments, limb amputations and/or compromised balance or grip [note 4]. The bent, sitting, position of the side saddle pose is 
also sometimes preferred by, and prescribed for, riders (both male and female) with certain types of back injury.

Aesthetical explanations are also suggested for the contemporary upsurge in side saddling. The side saddle habit dress, considered sometimes as elegantly demure, sometimes as sexually alluring, is a source of attraction to the sport (both for participants and spectators alike). Dressing the part, and also making reference to, and understanding, the rich heritage and nuances of side saddle attire and its related 'appointments' is an absorbing past-time and offers followers an outlet for connoisseurship and patronage of equestrian arts and crafts. A number of display teams - such as 'The Flying Foxes' formed in 2010 and 'A Bit On The Side' - exhibit the ancient art of side saddle riding in Britain at equestrian festivals, county fairs and national shows. Riding aside has been promoted by a number of charismatic and gifted poster girls, including Lady Martha Sitwell and jewellery designer Philippa Holland, who have done much to raise the profile, and develop the infrastructure, of the sport (in Britain particularly) over the last four to five years. 2013, for example, saw the inauguration of two high profile, now annual, side saddle competitions: the 'Leaping Ladies' high jump challenge held during the Aintree National Show and the 'Dianas of the Chase' [note 5] cross-country steeplechase hosted at Ingarsby Old Hall in Leicestershire. The official website of the latter event bears the slogan 'All Good Things Are Wild and Free' (Dianas of the Chase, 2014) and press and social media reports iterate the daring, courageous, athleticism of the competitors as well as the thrilling spectacle of the riders, horses and setting in combination (see, for example, Bowyer, 2014; Henton, 2012). 'They were braced for anything', went Tatler's coverage of the Dianas event in 2013, 'although there were only three actual spills, there were plenty of thrills. Every formerly immaculate girl charged toward the finish line coated in mud, whips going like Grand National winners' (Cockerill, 2013, p. 84). 
A further, final, influence on the return to prominence of side saddle riding may be attributed to the popularity - the phenomenon, indeed - of the British television period drama, Downton Abbey (first aired in the UK and Ireland on 26 September 2010). Set in post-Edwardian England, the series presents a view of family and servant life on an aristocratic country house estate in Yorkshire. Part and parcel of the depicted on-screen lifestyle shows the family - The Crawley's - participating in typical field pursuits such as hunting, hacking and racing. The eldest daughter, and siren of the ensemble, Lady Mary, is commonly featured aside, regaled in full habit dress faithfully reproduced in the Interwar style. This has led to the coining of 'The Lady Mary Effect' by the British press and the adoption of the phrase both in specialist equestrian circles and in popular parlance (see Audley, 2014; Mesure and Swinburn, 2013). Alice Audley (2014) of The Telegraph explains how 'the alluring image of Lady Mary, galloping around the estate, has women across Britain desperate to emulate her elegant style' and she reports a positive correlation between transmissions of Downton and enquiries for side saddle lessons received by riding schools.

This resurgence of interest in side saddle riding has brought with it some novel dilemmas, and the discussion continues here with a look at how contemporary practitioners are re-commissioning old saddles in response to a deficit of specialist kit. This discussion of objects from the past then segues into some conceptual terrain around the evocative and the sentient - and the artefact and the animal - in history. It then progresses, giving details of both the dress and the dress codes relating to female side saddlers in the early twentieth century before, finally, considering how the horse was implicated in these, too, as an active and vital agent. Nervous, frisky, leaping and cantering, the horse as a physical and a feeling creature had to be factored in to the design evolution and engineering of riding dress.

\section{HORSE BEFORE CART: REFRAMING RIDING DRESS RESEARCH}


The Side Saddle Association (SSA), a national organisation located in Great Britain, celebrated its fortieth anniversary in 2014 and reported a mushrooming membership numbering some 1400 devotees (SSA, 2014a). Both the saddles and habit dress used for riding aside are specialised artefacts and the products of labour intensive techniques, bespoke craft methods and niche manufacturing and supply. Horse and Hound magazine (subtitled 'Britain's Equestrian Weekly Bible') reported that Master Saddlers may take something akin to seven months to make a new side saddle and identified a 'desperate need' for antique models to assist in combating a 'serious shortage' as demand outstripped supply (Bankes, 2014). In July 2014, and in response to the dearth of specialist equipment, the SSA launched its Side Saddle in the Attic campaign, which encouraged the reconditioning and redeployment of older, previously used, side saddles. A press release, issued by the SSA, made the following plea:

Do you have, or know of, any side saddles not currently in use, or simply left lying around in your attic, tack room, barn or garage? ...The aim of the Association is to uphold the tradition of side saddle riding, not only for the next generation but for generations to come. We must protect our heritage; but without side saddles we do not have a future. The Association fully appreciates and understands that Granny's side saddle may be a treasured possession or is of sentimental value, but if it is not being used, perhaps you would consider bequeathing, leasing or selling it to one of our Areas or an individual member? Our members are prepared to pay a fair price and will unreservedly cherish and take pride in using and/or owning it, so please don't be afraid to entrust your valued side saddle to the next generation!

(SSA, 2014b) 
What is interesting here is the discourse of sentimentality running through the SSA campaign call. The narrative (above) acknowledges that current owners of old saddles invest in them emotive and personalised histories and that they may be family heirlooms with memories and meanings held, both materially and imaginatively, in, and through, the artefacts. As well as having a significant monetary worth, the value of used saddles extends to emotional regard, too. Once owned, perhaps, by a favourite, long deceased, relative or made for a treasured pet, saddles lie literally and metaphorically as the tract and trace between animal and human. Bearing the marks of wear or repeated scuffing from the movement both of horse and rider, a used saddle has the patina, indenting and imprint of a corporeal experience. Saddles are used for the horse-human activity of riding and are, therefore, the products of a process. Over time, their doe skin-covered seats capture and absorb the sweat from human and animal bodies in action. They are buffed and polished. They are waxed ritually and repeatedly, being, in a sense, nourished and maintained as with the care of a sentient creature. Saddles, too, may retain, or be stained by, the dye [note 6] of poorly 'fixed' historical habits that have chaffed and rubbed against leather, flesh and fabric. Saddles are slowly moulded by both the warmth of the sentient beast and the body weight and shape of the human passenger. They become discoloured and weathered through prolonged exposure to the elements. They are darkened by rainwater and dried by the sun. Saddles are, then, infused with traces climatological, cultural and corporeal. They have stories held within, and around, them. They are dynamic, changing, perhaps even breathing and living, objects.

Turkle's (2007) writing on evocative objects is useful here in that she urges us, as scholars, to consider how (mundane) items may be regarded as more than either necessities or vain indulgences but how they may also act as a bridge between intellect and emotion. She writes how: 
We are on less familiar ground when we consider objects as companions to our emotional lives or as provocations to thought. The notion of evocative objects brings together these two less familiar ideas, underscoring the inseparability of thought and feeling in our relationship to things. We think with the objects we love; we love the objects we think with.

(Turkle, 2007, p. 5)

One only has to look at the advertisements generated by the Side Saddle in the Attic appeal to find evidence of the emotional - and deeply human - nature of the attachment to antique equestrian kit: 'been in same family for 50 years'; 'loved and well cared for'; 'good home essential for this much loved saddle'; 'with the same owner since the 1950s'; 'the padding may need redoing but this saddle has got a future with a new rider'. The advertisers cited here posit their wares as treasured possessions in need of affectionate, loving, new 'homes', seeking buyers with sympathetic appreciations of the historical and cultural provenance, as well as the material properties, of the objects for sale. Indeed, the rational economics of the marketplace often appear to be secondary in these transactions as several side saddles are lodged on the SSA bulletin board as available for purchase at a 'negotiable' price: profit, this may suggest, not necessarily being the prime driver behind these emotionally-charged exchanges (SSA, 2014c).

Along with the evocative historical object (in this case, the side saddle) as a vehicle for channelling feelings - and thinking - it is useful, at this juncture, to consider, too, the growing body of academic work on animals, agency and evocation (for example, Daston and Mitman, 2006 ; Fudge, 2002). Mirroring the language used by Turkle (see above), LéviStrauss (1963, p. 89) urged anthropologists to acknowledge the ways in which animals afford humans an important conceptual resource, arguing that animals are 'good to think with.' 
[note 7] So often depicted in academic studies as passive objects bereft of human agency, animals have been overlooked, or undervalued, as historical, and evocative, actors. Writing of the horse in military history, for example, Phillips (2013, p. 164) suggests that academics 'remain fundamentally anthropocentric in their approach. Their attitudes towards the horse are essentially instrumentalist, telling of how man has procured, employed, regarded and cared for the horse.' Swart (2007, p. 276) argues similarly, writing that 'the physical animal is missing' from scholarly works and calling for historians to seek the visceral, sentient and corporeal animal outside of, or beyond, its representation in, and through, (humanconstructed) words and texts. Swart's $(2007 ; 2008 ; 2010)$ collected works, in their focus on horses and history, are particularly pertinent to the framing of the discussion presented here. As Swart (2007, p. 276-7) puts it: 'horses are breathing beasts, which exist and live historical lives and impact their own world and on the world of humans socio-politically, and economically.' The argument presented in this chapter is influenced by these ideas and embarks on the task of writing the animal in to history, and, significantly, of writing the horse in to riding dress history in particular. Existing academic literature that deals centrally with the history of female riding dress, although modest in volume, forms a useful foundation on which to build. To date, however, the work has tended to focus on the Victorian era (Bartsch and Trautmann, 1987), or earlier (Arnold, 1999; Blackman, 2001; Cunnington and Mansfield, 1969) and has largely disregarded the horse as a player of any note in the sartorial narrative. Instead, studies have considered the changing form of the dress artefacts themselves over time (Albrecht et al, 1988; Foster, 1969) and/or the social politics of their human wearers (Goodrum, 2012; Matthews David, 2002).

\footnotetext{
*Insert figures 2 and 3 about here*
} 
Figures 2 and 3: Dress pattern for a 'safety riding skirt', a design bearing some resemblance to Hayes's earlier version, taken from Engelmann's American Garment Cutter for Women's Garments, 1913. Figure 2 illustrates the curious structure of the back panel to the skirt, which has an arc-shaped cut away vent (as shown on the female form in figure 3).

Figure 3 depicts the ways in which the skirt is worn both when mounted and when unmounted (that is, with the safety vent closed via a wrap-over, buttoned, fold of fabric to cover the legs and derrière). Figure 3 also shows the position of the internal elastic stirrup and leg strap that function to hold the skirt in place when riding.

The discussion here uses the approach developed in animal studies to explore the impact that the horse had both on the design of the riding habit but also on its wearing and wearers - on the humans - too. Horses, it is contended here, were actively implicated in the design construction of the habit, how it functioned, the form it took and also the feelings, and meanings, it evoked. This point is elaborated in the discussion below but by way of brief illustration here, the example of Alice Hayes's side saddle 'safety skirt', patented in the 1890s, is instructive (see figures 2 and 3). Alice Hayes, along with her husband, a British army officer, was an authority on the horse and, during overseas postings, gathered information on all matters equestrian, drawing from a variety of cultures and traditions. In her guide to riding, The Horsewoman, of 1903 [1893] [note 8], Hayes describes how the temperament of her horse was instrumental in the prototyping and trialling of her antidragging skirt innovation. The safety skirt comprised a cut away opening at its back that, in the event of a fall, prevented it from being caught up in the pommels and pulling the wearer perilously along the ground. The design included a novel buttoning arrangement that, for modesty's sake, allowed the open back vent of the skirt to be fastened together upon dismounting. 'I had a nice quiet horse' explained Hayes (1903 [1893], p. 95) in her account 
of the design process, 'who allowed me to thoroughly test my invention by falling off his back in every conceivable direction, my husband being present to prevent my voluntary fall from degenerating into a "cropper." Extending the idea that animals are good to think with, this example illustrates that there are historical cases in which they have also been good to innovate and create with too. One could even go as far here as to present Hayes's horse, a creature of quiet sensibilities - a sentient, sensitive animal - as a collaborative agent in the development of her new style of habit skirt.

\title{
POINT SCORING: THE DO'S AND DON'TS OF RIDING TURN OUT
}

\author{
*Insert figure 4 about here*
}

Figure 4: In partnership, this unknown horse and rider from the Meadow Brook Hunt Club (c.1939) exemplify good hunting turn out and demonstrate the principles of plainness, neatness and correctness. It is customary to portray side saddle horses from this angle in art works, showing the physiology of the animal rather than the material expanse of the rider's habit dress (which falls on the other, far, side of the horse). The format of the equestrian portrait has its roots in a gender dynamic drawn from ancient chivalry whereby males positioned themselves to the right (in order to draw arms) when accompanying females. Here, the photographer presents a view of the horse and rider according to this lore. Source: National Sporting Library \& Museum, Middleburg, VA.

Between 1900 and 1939, female side saddlers, particularly in the highly formalised settings of the hunting field or show ring, were subject to a mix of stringent social, sporting and sartorial expectations [note 9]. These involved meeting (or attempting to meet) perceived standards of perfection in personal appearance and self-presentation: of being 'well turned out' (see figure 4). In competition at a horse show one's turn out was literally assessed 
(against standards of correct colour, styling, fabric, cleanliness and so on) and was part of an entire raft of 'appointments' that encompassed appearance (such as bearing, complexion and hairstyle), tack (its type, maintenance and display) as well as, highly subjective, judgements to do with the preferred grooming, physiology and looks of the horse. As the equestrian journalist, Elizabeth Grinnell (1928, p. 54), cautioned in an article on show attire in The Sportsman of September 1928, 'many a ribbon has been lost by a wrong saddle and bridle or an improperly dressed rider.' In the hunting field, judgements of sartorial taste and propriety were of similar import and adjudicated, if not by the awarding of points, nonetheless as keenly. The Master of Fox Hounds and the hunt club officials were meticulous in inspecting riders, kit and horses at the start of a meet (and were not beyond bawling out, or sending home, offenders who fell short of standards). Ordinary members of the field would also pass, often somewhat derisory, comment on the turn out of their peers so that, as a social and sporting faction, riders upheld their own codes of dress and taste through informal techniques of peer surveillance and self-monitoring. Equestrianism was, then, as much about skill in the art of appearance management as it was in the art of riding. Those women that demonstrated poor taste or 'got it wrong' were open to satire and disdain (or, at worst, contempt and mockery), as the following passage from the instruction book, Women In the Hunting Field, by A. C. Stewart Menzies (1913, p. 15) bears out:

Be sure you have your breeches made of material the same colour as your habit. You may say to yourself, of course I should never dream of having my nether garments made of any other colour. Quite so, but then I have seen some very odd things indeed that way among those who ought to know better. Not long ago I saw quite a well known follower of a South country pack get off her horse to lead it over an awkward place, and behold! an expanse of large black and white check breeches not in their 
first youth, and when I explain the individual was not of slender proportions I feel the picture is complete.

(Stewart Menzies, 1913, p. 15)

Perfection in riding attire was defined through simplicity, sobriety and restraint (for further discussion see Goodrum, 2012 and Matthews David, 2002). Sharp tailoring, dark colouring, smooth lines and a disciplined, contained, body were organising principles of the equestrian ethic. The descriptors 'neat', 'tidy', 'smart' and 'plain' were recurrent in instructional texts of the period, all of which devoted entire chapters to the discussion of correctness in dress (see for example Beach, 1912; Christy, 1932; Hayes, 1903 [1893]; Houblon, 1938; Sheddon and Apsley, 1932). For example, Stewart Menzies (1913, p. 25-6) counselled her readership that, 'it does not matter one little bit how old your clothes are, so long as everything is correct, nothing untidy, nothing outré. You may then feel at peace with the world at large.' And, espousing a similar doctrine in the following extract, taken from Riding and Driving For Women of 1912, Beach defined the ethic of formal equestrian dress thus:

To look well in the saddle a woman must be correctly and smartly turned out. The picturesqueness of the old-fashioned skirt, the plumed hat, and the ambling palfrey has passed away, and a woman's riding clothes of to-day are designed, first for comfort, and second, for neatness. Absolute plainness and everything in keeping are the principles to be followed.

(Beach, 1912, p. 108) 
While some of these dictates may appear to be nothing more than obscure foibles, most of the etiquette surrounding turn out originated, in some way, in functionally-motivated concerns for the safety, comfort and efficiency of both rider and horse. Being well turned out was more than a beauty parade or best dressed competition. As Hayes (1903, p. 13) put it 'hunting women, as a rule, do not pay much attention to the good looks of their horses, for hunting is not a church parade, and the finest performer over a country is always admired and coveted whatever his appearance may be.' An important nuance, then, was that in the equestrian world, handsomeness and attractiveness were defined, not through prettiness per se, but through an appearance that was 'workmanlike' [note 10] (a term used repeatedly in contemporary writing on riding turn out) whereby serviceability and appropriateness of tack, horse, dress and human were prized. In discussing the merits of riding boots, for example, Stewart Menzies (1913, p. 19) endorsed thick soles for their workmanlike looks (and thin ones for their practical ability to assist with grip). She also condemned certain finishes of leather, regarding patent leather to be unrefined (an aesthetic judgement) and buttoned leather to be a potential risk hazard (a practical judgement). She wrote of what she termed, unusually, as her 'Wellington' boots for riding and her preference for having

...the soles not too thick, so that the stirrups are easily felt, but many people like them thick, and I must allow they look more workmanlike than when they are thin. So this is a question you must consider well before deciding. Never, never wear patent leather boots or buttoned ones. Patent leather are vulgar and unpardonable, while buttoned ones are highly dangerous, murderous things. They may catch and prevent you getting your foot out of the stirrup quickly, besides which they are out of keeping and not correct.

(Stewart Menzies 1913, p. 19) 
Stewart Menzies' discourse (above) on boots illustrates how being workmanlike was constructed around a conflation of material and aesthetic properties: both of serving well and of being tasteful. It is important to point out, however, that these judgements of good turn out applied to more than individual appointments and the small nuances and minutiae of tack, kit, clothes and appearance. Doubtless, turn out was about the exact positioning of the balance strap; it was about the stowing of spare rain gloves, folded together fingers forward, under the girth; it was about the tie pin being attached perfectly horizontally to the hunting stock. But, so too, turn out was about the fuller effect of the horse and rider ensemble: the perfection of the partnership between animal and human.

The aesthetical balance of the partnership was a consideration that penetrated back into the supply and manufacturing chain of the habit garment. The overall look of the horsehuman-habit relationship was constructed and curated, in part at least, within the (male) tailor's workroom, a space removed, even at odds with, the natural environs of the equestrian world. As a way of bridging the gap, specialist tailors provided wooden blocks and trestles that were hewn to a horse-like shape (refer to figure 1). These allowed clients to try out the fit, feel and effect of their attire in, what was for the side saddle rider, an unusual, twisted, mounted position, as on horseback. Women were encouraged to bring their own saddles along to fittings, of which there may have been as many as three or four, to ensure a bespoke, perfect, fit. Stewart Menzies (1913, p. 16) supplied further advice for the side-saddler's visit to her tailor:

Get into the saddle provided for the purpose in the fitting-room, and make sure they [one's riding breeches] are quite comfortable. In neat breeches there is no occasion to be coy about being seen in the saddle (or out of it for that matter) without your skirt or 
apron; the day has gone for that sort of thing with the times when women screamed and fainted on hearing a gun fired. If you wriggle and blush you only make the unfortunate fitter uncomfortable and think you a fool.

(Stewart Menzies, 1913, p. 16)

The physiological balance of the partnership between horse and rider was alluded to by Hayes (1903 [1893], p. 19-20). What is interesting is that she defined 'looking well' on a horse in - starkly - corporeal terms so that being slim or stout were body-related concerns with the potential to impact on judgements of proportion, line and scale. 'The style of hack should be in thorough keeping with that of the rider', she wrote, 'a slight lady has a greater range of choice in horseflesh than a portly dame.' In a similar vein, Beach (1912, p. 110) also took up the theme of proportion, referring to the clothed silhouette of the well turned out rider when mounted. She expressed a preference for a linear and angular effect, thus: 'unless a woman's shoulders look wider than her hips, she will never present a smart appearance on a horse...the effect should be of broad shoulders, slimness, neatness, and ease; of long lines rather than curves'. Stewart Menzies (1913, p. 33) too, championed 'long sloping lines' in riding dress. She waged war on a range of bodily defects among female riders including corpulence, sore eyes, rough skin, blemishes, weak muscles and poor health. Her manuscript included a number of exhortations on beauty and diet in, and for, the hunting field, as well as recipes for homemade elixirs and slimming tonics, and recommended brands of medicament. 'I have always maintained', she wrote (1913, p. 28-9) with a sternness of principle, that, 'it is part of our duty towards our neighbour to make ourselves as little repulsive as possible.'

\section{LEAPS AND BOUNDS: OF HORSES, HABITS AND HUMANS}


The side saddle 'safety skirt', as discussed above in relation to Alice Hayes's innovation of the late Victorian period, was not universally lauded. Buxton $(1987$, p. 66) tells us, for example, that an entire generation of Victorian huntswomen 'viewed the introduction of the so-called "safety skirt" with scorn, dubbing it "the fig leaf".' While it served its intended purpose as a protective item, it met with disapproval due to concerns with decorum that outweighed cares for safety. The garment was created to unbutton or fall away from the wearer in an emergency, thereby revealing the woman's legs wrapped snugly in close-fitting, tailored, breeches, which were worn as a layer under the skirt. This exposure of the female form, even when clad, was considered indecent by a marked majority of the sporting field (and, certainly, by contemporary society at large [note 11]) well into the 1920s. As Matthews David (2002, p. 186) notes 'however practical they might be, a woman had to conceal her breeches until the second decade of the twentieth century.' There were, of course, exceptions. For example, Betty Babcock, a member of the Meadow Brook Hunt of Long Island, New York, noted in her illustrated, satirically-laced, hunting diary from the 1936-7 season that 'Madame Murnane heralded the approaching spring by discarding her skirt and with her new found freedom urged the faithful Page Boy [her horse] to the most violent activity'(Babcock, 1937). Houblon, writing around the same time, in 1938, also suggested that, for informal side saddle riding, the habit skirt might be dispensed with. So that, 'for ordinary hacking in the country what need is there to cover with a skirt a well-cut pair of Jodphurs or boots and breeches, on a figure that would go about skirtless quite happily were she riding astride?' (Houblon, 1938, p. 5).

Propriety, or lack thereof, in the intentional exposure of breeches was cited as part of the case against female cross saddle (or astride) riding at this time, an activity which called for the wearing of a bifurcated garment of some kind. The arguments for and against astride riding for women see-sawed between the years 1900 and 1939, and were never resolved 
entirely [note 12]. Breeches, due to their figure hugging design, were considered too form enhancing - and therefore sexually provocative - by some opponents of the cross saddle for women, and too masculine by others. Writing in 1932 (p.140), Sheddon and Apsley observed that 'there is still considerable divergence of opinion as to the correct get-up for women hunting astride; the great thing is to avoid the appearance of a hermaphrodite or someone's groom!' Even the making of a woman's breeches (be it as under layers for side saddlers or as outer garments for astride riders) solicited concerns pertaining to decency. As we saw in the discussion of wooden horse blocks, above, riding habits were specialised outfits originating in the masculine tradition, and were bespoke made, being cut, constructed and fitted by master (male) tailors, as far as modesty would allow. Hayes (1903 [1893], p. 110) elaborates this point, illustrating the restrictions imposed on the male tailor with his female equestrian clientele:

It used to be extremely difficult for ladies to get a properly-fitting pair of riding breeches, as no correct measurement for them was taken, and it was not pleasant to be obliged to interview male fitters respecting the cut of these garments. Messrs. Tautz and sons, of Oxford Street [London], solved the difficulty by providing us with a competent female fitter, who takes careful measurements for breeches, and rectifies any faults there may be in their fit.

(Hayes, 1903 [1893], p. 110)

Strangely, the safety skirt was also maligned as much for its modesty of design as its immodesty. The potential for embarrassment (a flash of breech-clad thigh, say) was one thing, as we have seen in the foregoing discussion. Yet criticisms were also pitched at the safety skirt due to its cumbersome swathes of fabric that functioned to ensure the wearer was 
able to keep her legs and backside covered, demurely, during all possible manoeuvres required of the horsewoman both in and out of the saddle (and, indeed, whilst getting in and out of the saddle). Buxton (1987, p. 66) writes about the excess of heavy habit cloth and the peculiar aesthetic effect this had on the hang of the skirt and its aesthetic line when out of the bent-kneed, side saddle, pose (figure 5): 'when on foot it contained far too much material ever to look other than strange.'

*Insert figure 5 about here*

Figure 5: Miss Catharine G. Mellick hunting with the Essex Fox Hounds, New Jersey, 1939. Mellick wears side saddle attire, including a distinctive 'cut away' habit coat and an apronstyle side saddle safety skirt. The skirt is more streamlined than some of the earlier safety skirts and, somewhat unusually, has an internal cavity that accommodated the bent position of the right knee when mounted. This design feature is betrayed by the peculiar bunched effect of the upper skirt and illustrates how habit attire did not always translate well out of the saddle. Source: National Sporting Library \& Museum, Middleburg, VA.

At the turn of the century, the safety skirt was one of several anti-dragging designs from which a rider might choose according to preference and availability. Over time, the volume of the habit skirt became pared down, and, by the 1920s, the safety skirt had morphed into more streamlined 'apron' and 'half-apron' [note 13] safety styles which were less bulky. Beach (1912, p. 110) explains the configuration of the apron skirt thus: 'the skirt is entirely cut away on the side next to the horse so that, when the rider is mounted, her legs are in direct contact with the saddle.'

No matter what the style of the habit skirt, however, it is undeniable that it remained a garment of significant material yardage, comprising a sizeable quantity of darkly-hued, hard 
wearing Melton, whipcord or broadcloth textile (figure 6). If these skirts were unwieldy for the female rider, then they too interfered with, or were at least troublesome to, the horse. Horses were trained specially to carry side saddles, and as part of this process of breaking in, they also had to be trained to become accustomed to the vast expanse of fabric that was the side saddle skirt. With the potential to flap about in the wind, to fly up over a jump and to flop around on mounting, the skirt was a source of unease and anxiety for an inexperienced horse. As Houblon (1938, p. 3) warned "when a horse encounters "drapery" for the first time he may quite possibly think it strange.' Hayes (1903 [1893], p. 440), too, offered counsel on those horses that she described as being 'habit shy'. 'I use this term', she wrote 'to designate the trick that some horses, chiefly those which are unaccustomed to the side-saddle, have of sidling away from the skirt.' Both experts - Houblon and Hayes alike - recommended that a groom be engaged to assist in the steady initiation of the horse to, mocked-up approximations of, the skirt's fullness. For example, a rug worn by a groom at exercise or a long mackintosh were suggested as proxy devices to be used in the training of a habit shy equine.

*Insert figure 6 about here*

Figure 6: Original caption reads, 'At the Unionville Hunt. J. Stanley Reeve and his daughter Kathryn are regular hunters.' Circa 1940. Kathryn is dressed in side saddle turn out that illustrates the expanse of the habit skirt. Source: National Sporting Library \& Museum, Middleburg, VA.

In addition to the habit skirt, other items of side saddle dress were a possible source of emotional, and physical, reaction for the horse. These reactions, in turn, present a form of testimony for the horse in history as a thinking, feeling, animal: one that experienced and demonstrated panic and fear triggered by the eccentricities of side saddle attire. A side 
saddler's top hat, for example, was something of a nerve-inducing hazard for the horse. No matter how well-fitting, when the horse was leaping, prancing, galloping and racing, the smartly buffed, beaver fur, hunting topper was poised precariously, and frequently teetered and toppled off the rider's neatly coiffed head. Turn out etiquette attempted to mitigate the insecure tendencies of the top hat through the use of securing veils, hat guards, hairstyling and elastic straps. These had a dual purpose, both to retain the hat for the rider but also to prevent the hat from tumbling on to the horse and causing it to startle. Hayes (1903 [1893], p. 459-60) supplies a colourful vignette of this, the perilous dynamic between hat and horse. She refers to her pith helmet, which she wore as a concession to the tropical climes, during an equestrian sojourn to India:

I remember one very handsome Waler [note 14], which went like a lamb with me until suddenly, when cantering quietly along, he took it into his head to try to buck me off. He did his best to accomplish his purpose, and was encouraged in his efforts by my pith hat coming off and flopping about my head. I wished the thing could have fallen, but it was held by the elastic - we wore our hair in plaits at the nape of the neck in those days - and I had securely pinned the elastic with hairpins under my hair. This great wobbling hat only caused the horse to buck worse than ever, until he tired of his performance and came to a sudden halt. I was greatly exhausted and suffering from mental tension, because I was entirely unprepared for this attack, and doubted the security of my stronghold.

(Hayes, 1903 [1893], p. 459-60)

The side saddle rider, and her habit maker, employed all manner of ingenious mechanisms in order to maintain - or attempt to maintain - perfection of turn out as the horse functioned as a 
sentient, corporeal and active being. For example, elastic foot straps were sewn to the inside of the habit skirt (refer to figure 3) to assist in holding it in place as the horse went over jumps. Lead weights were stitched into the hem of skirts, too, to serve a similar purpose and button fastenings anchored the waist of the skirt to the bottom of the habit coat in order to prevent it from riding up when in motion or urging a horse forward. The construction and design of riding dress also developed to moderate and manage the effects of the horse as a physical, bodily, living, beast that secreted and perspired. Riding manuals, for example, suggested that women should line the tails of their jackets with rubber or leather in order to counter the effects of the horse's sweat as it made contact with the cloth of the coat. 'The sweat of the horse', explained Stewart Menzies (1913, p. 14), 'can then easily be sponged off.'

\section{CONCLUSION}

This interaction between the material fibres of the habit coat and the oily secretions from sweaty horseflesh is appropriate as a final, summative, example on which to round off the discussion here. Cloth fabric had a propensity to absorb bodily deposits from the sweating, perspiring, horse. Subsequently, in turn, the properties of that cloth fabric were altered, biochemically, as equine oils and sweaty fluids were dissipated into, and soaked up by, its material structure. After (possibly) seven or eight hours in the hunting field or during the high octane exertions of a three mile point-to-point race, a rider's coat would likely be soggy or damp to the touch and, perhaps too, have taken on a horsey, beastly, aroma. The horse, then, impacted the dress of its rider in physical and sensory ways and, as we saw similarly with the discussion above of the used antique side saddle as an evocative object, was able, literally and metaphorically, to permeate and impact its surface. Bearing this in mind, the chapter has made a case for the dynamism of the horse-human-habit relationship and has 
suggested that the horse played an active role in forming, and informing, the design of the habit during the early decades of the twentieth century. Equally, the horse was implicated in the way in which the habit was worn, functioning as one half of a partnership (along with the rider) directed by the rules and regulations of formal turn out criteria. Being well turned out, historically, was about both the horse and rider being held to high standards of smartness and grooming and to ideas of perfection built around the conceit that excellence was manifest in functionality, appropriateness and decorum. The discussion here has forwarded the contention that the side saddle riding habit may be posited as an evocative object through which to think about its history and its heritage and, also, about the way in which that history and heritage may be approached through fresh and invigorating, beastly, trajectories.

Drawing on, and developing, the advocacy of animal studies, then, writing the horse into riding dress history affords an opportunity for the enrichment of understanding mediated through the sensory, sentient and (the) animal. The discussion here confirms that side saddle dress was complex indeed, comprising a set of garments that were unusual in construction, appearance and configuration. However, side saddle dress was also complex in terms of the socio-cultural discourses and contemporary behavioural and bodily dictates written and rewritten across it. Fast forwarding some hundred years or so to the growing league of side saddle practitioners today, this complexity of material and meaning holds enduringly true, if somewhat altered, adapted and reinterpreted for the twenty-first century. By way of ending, it remains relevant, then, to cite the concluding lines borrowed from Amory's style column on the 'burden' of riding dress in The Sportsman, March 1933:

Soft lights and teagowns are often ambiguous, But a woman on horseback is very conspiguous [sic] (Amory, 1933, p. 51) 


\section{NOTES}

1. Riding dress was, and remains, divided into two broad categories: 'formal' and 'informal' attire. Informal riding dress was relaxed and less uniform in appearance, and often sported for the casual activities of hacking or trekking. Formal riding dress was highly regulated, and in the hunting field was worn during the 'formal' fox hunting season (autumn through to the beginning of summer). To clarify, this chapter is concerned with formal riding attire, particularly that of hunting and showing.

2. Swart's (2007) 'but where's the bloody horse?' is a homage to Roy Campbell's poetic work On Some South African Novelists.

3. Brooksby was better known as Major Elmhirst, aide-de-camp of Lord Roberts of Kandahar (1832-1914), an acclaimed commander of the British Army in India. Brooksby wrote anecdotally of sport and hunting in Southern India and Leicestershire during the mid to late nineteenth century.

4. Interestingly, E. V. A. Christy, author of several equestrian titles (1899; 1932; 1947), was involved in rehabilitative riding programmes after World War One and championed the possibilities of the side saddle for use with prosthetic limbs. Sheddon and Apsley (1932, p. 102), also provide an historical connection between side saddle engineering and adaptation to/for physical injury. They wrote in 1932 that, 'the lower leaping pummel is said to have been invented by Thomas Oldaker, huntsman to Earl Berkeley (1788 to 1820), after he broke his leg, and trying to hunt side-saddle found he could not jump fences without a grip for his left leg.' They also made a case for the stability afforded by 
the side saddle seat, writing how 'it is significant that a certain girl took eleven tosses in a season hunting astride, while of three others side-saddle in the same sort of class, only one had a single fall during the same period' (Sheddon and Apsley, 1932, p. 93).

5. Philippa Holland, founder of the Dianas of the Chase competition 2013, cites a newsreel clip showing a side saddle steeplechase from the 1920s as the inspiration behind her rekindling of the race (Pithers, 2013). It is likely that the footage in question is from British Pathé, 12 April 1923, featuring the South and West Wiltshire Hunt (British Pathé, 1923). This link between side saddle racing in 2013 and 1923 is useful in that it offers a rationale for the historical timeframe and the past-present dynamic around which the discussion in the chapter is shaped and structured.

6. Hayes (1903 [1893], p.90, refer also to note 8 below) mentions this effect in her historical tome on side saddle riding: 'an experienced saddler has drawn my attention to the fact that the dye from skirts made of cheap shoddy material, is apt to come off and seriously injure the leather of the saddle.'

7. The exact wording of this much-cited quotation from Totemism is subject to translation, and perhaps mistranslation, from the original French phrasing bonnes à penser (literally, ' $g o o d$ to think').

8. The second edition, published in 1903, of Hayes's book, The Horsewoman, is used in the production of this chapter since this later version falls squarely within the designated timeframe of this study and, according to Hayes's opening pre-amble is 'practically a new book' (1903, p. viii). The frontispiece of the second edition states that the book has been 
'revised, enlarged and 133 photographic illustrations added.' The first edition was published in 1893.

9. It should be noted that female side saddlers were held to strict dress codes prior to 1900 , too. Blackman (2001) suggests that women's habit dress began to be formalised as far back as the early 1760s (referring to a portrait by Joshua Reynolds), when women began to wear special outfits for riding rather than their everyday clothes (as had been the case up until this point). Codes of riding dress, for men and women, became highly regulated in the Victorian period, the legacy of which remains in formal equestrian turn out today.

10. Matthews David (2002, p. 182) discusses the use of 'workmanlike' in equestrian writing and notes that a 'language of labor' $[$ sic $]$ is apparent in riding literature from the earlier Victorian period.

11. Goodrum (2012, p. 89) tells us of the spatial specificity that governed female trouserwearing during the early decades of the twentieth century. 'Breeches for women were confined unequivocally to the spaces of riding - and not beyond to wider society.' Campbell Warner (2005, p. 90) elaborates this point with reference to the USA during the 1930s: 'trousers were acceptable only on beaches, in resorts, occasionally on campuses, or in back yards of private homes - and then primarily only on young women. Never would a fashionable woman wear trousers to work, to shop, or to do any serious activity.'

12. During the period in question (1900-1939), it seems there was no consensus on the appropriateness of the emerging fashion for women to ride astride, and whether it would endure. For example, in 1913 (p. 35), Stewart Menzies wrote, 'why people turn up their 
eyes and cluck on seeing women and girls riding astride, I cannot imagine! Of one thing, however, they may be certain, the method has come to stay as surely as has motoring or flying.' Only a year earlier, however, Beach (1912, p. 39) denounced the cross saddle for women, thus: 'it is only those women who are built like men and very young girls who look at all well astride. A woman with merely a normal developed figure looks both ridiculous and immodest.' By the mid-1920s, it was not unusual for women to be skilled at traditional side saddle riding as well as the cross saddle technique (and to interchange between the two as preferences, protocol and resources allowed). Writing in 1932, Sheddon and Apsley (1932, p. 91-2) noted that the question to go aside or astride was 'a moot point', and they advised their readership that 'to-day a woman may please herself entirely as to which seat she adopts without upsetting anyone.'

13. Broadly-speaking, the half apron model, which gained popularity and prevalence in the 1920s has endured and a recognisable version of it continues to be sported by many side saddle riders today.

14. A 'Waler' is a breed of Australian horse. The name derives from the Australian colony, New South Wales.

\section{REFERENCES}

J. Albrecht, J. Farrell-Beck and G. Winakor (1988) 'Function, Fashion and Convention in American Women's Riding Costume, 1880-1930', Dress, 14, 56-67.

Amory (1933) The Sportswoman Observes, March, XII, XI, 46-51. 
J. Arnold, (1999) 'Dashing Amazons: The Development of Women's Riding Dress, c. 15001900' in A. de la Haye and E. Wilson (eds.) Defining Dress: Dress As Object, Meaning and Identity, (Manchester: Manchester University Press).

A. Audley (2014) 'Can I Match Lady Mary’s Elegance in the Side Saddle?', The Telegraph, 1 August.

B. Babcock (1937) Betty Babock's Illustrated Hunting Diary: Recording the Sport of the Season For the Followers of the Meadow Brook Hounds1936-1937, (New York: Ernest Gee, Privately Printed).

C. Bankes (2014) 'Call for Side Saddles to Combat Shortage', Horse and Hound, 27 July.

D. Bartsch and P. Trautman (1987) 'Skirts for the Nineteenth Century American Equestrienne', Dress, 13, 21-33.

B. Beach (1912) Riding and Driving For Women, (New York: Charles Scribner's).

C. Blackman (2001) 'Walking Amazons: The Development of the Riding Habit in England During the Eighteenth Century', Costume, 35, 47-58.

G. Bowyer (2014) 'Dianas of the Chase', Horse and Hound, 22 March, 92. 
British Pathé (1923) 'Dianas of the Chase. Lady Members of South and West Wiltshire Hunt Compete in 3 1/4 Mile Point To Point Race. Gillingham', http://www.britishpathe.com/video/dianas-of-the-chase, date accessed 4 December 2014.

M. Buxton (1987) Ladies of the Chase, (London: The Sportsman's Press).

P. Campbell Warner, (2005) 'The Americanization of Fashion: Sportswear, the Movies and the 1930s', in L. Welters and P. Cunningham (eds.) Twentieth-Century American Fashion, (Oxford: Berg)

E. Christy (1899) Side-Saddle Riding: A Practical Handbook For Women, (London: Vinton \& Co).

E. Christy (1932) Cross Saddle and Side-Saddle: Modern Riding for Men and Women, (London: Seely Service).

E. Christy (1947) If Wishes Were Horses Beggars Could Ride, (London: Ivor Nicholson and Watson Ltd).

A. Cockerell (2013) 'Boing! Bit On The Side', Tatler, April, 81-84.

P. Cunnington and A. Mansfield (1969) English Costume for Sports and Outdoor Recreation: From the Sixteenth to the Nineteenth Centuries, (London: A\&C Black). 
L. Daston and G. Mitmen (eds.) (2006) Thinking With Animals: New Perspectives On Anthropomorphism, (New York: Columbia University Press).

Dianas of the Chase (2014) Homepage, http://dianas-of-the-chase.com/, date accessed 27 November 2014.

J. Druesdow, (1984) ‘Aside and Astride: A History of Ladies' Riding Apparel' in H. Mackay-Smith (ed.) Man and the Horse (New York: Metropolitan Museum of Art/ Simon and Schuster).

G. Engelmann (1913) The American Garment Cutter for Women's Garments, (New York: American Fashion Company Publishers), $2^{\text {nd }}$ edition.

L. Fleitman Bloodgood (1959) The Saddle of Queens: The Story of the Side-Saddle, (London: J. A. Allen \& Co).

I. Foster (1969) 'The Development of Riding Costume c. 1880-1920', Costume, 3, 55-60.

E. Fudge, (2002) 'A Left-Handed Blow: Writing the History of Animals' in N. Rothfels (ed.) Representing Animals, (Bloomington, Illinois: Indiana University Press).

A. Goodrum (2012) 'A Severity of Plainness: The Culture of Female Riding Dress In America During the 1920s and 1930s', Annals of Leisure Research, 15, 1, 87-105. 
S. Grant (1978) 'Evolution of the Amazone in Life and Literature', National Sporting Library Newsletter, December, 7, 1-4.

E. Grinnell (1928) 'Correct Attire for The Show Ring', The Sportsman, September IV, III, 54-98.

A. Hayes (1903) [1893] The Horsewoman: A Practical Guide to Side-Saddle Riding, (New York: Charles Scribner's), $2^{\text {nd }}$ edition.

B. Henton (2012) 'Aside, Not Astride', The Field, June, 101-3.

D. A. Houblon (1938) Side-Saddle, (London: Country Life Ltd).

C. Lévi-Strauss (1963) Totemism, (London: Merlin Press), trans. R. Needham.

A. Matthews David (2002) 'Elegant Amazons: Victorian Riding Habits and the Fashionable Horsewoman', Victorian Literature and Culture, 30, 1, 179-210.

S. Mesure and Z. Swinburn (2013) 'The Ladies Going Hell For Leather: "Downton Effect" Sees Riding Side-Saddle Return With A Vengeance', The Independent, 20 October.

L. Peralta-Ramos (2000) The Mastery of Munnings: Sir Alfred J Munnings 1878-1959, (Saratoga Springs: National Museum of Racing). 
G. Phillips (2013) 'Writing horses into American Civil War History', War In History, 20, 2, $160-181$.

E. Pithers (2013) 'Philippa Holland On Her Goodwood Riding Schedule', The Telegraph: Fashion, $25^{\text {th }}$ July.

D. Sheddon and V. Apsley (1932) 'To Whom The Goddess... ': Hunting and Riding for Women, (London: Hutchison and Co).

SSA (2014a) The Side Saddle Association: About Us, http://www.sidesaddleassociation.co.uk/index.asp, date accessed 25 November 2014.

SSA (2014b) The Side Saddle Association: Press Release. 'Is There A Side Saddle In Your Attic?', 21 July 2014.

SSA (2014c) The Side Saddle Association: For Sale and Wanted Adverts, http://www.sidesaddleassociation.co.uk/salewantedadverts.asp, date accessed 25 November 2014

A. Stewart Menzies (1913) Women In The Hunting Field, (London: Vinton and Company).

S. Swart (2007) “"But Where's the Bloody Horse?”: Textuality and Corporeality in the “Animal Turn”, Journal of Literary Studies, 23, 3, 271-292. 
S. Swart (2008) 'High Horses" - Horses, Class and Socio-Economic Change in South Africa', Journal of South African Studies, 34, 1, 193-213.

S. Swart (2010) "“The World the Horses Made": A South African Case Study of Writing Animals into Social History', International Review of Social History, 55, 241-263.

S. Turkle (2007) Evocative Objects: Things We Think With, (Cambridge MA: MIT Press). 